KOŚCIÓŁ I PRAWO 8(21) 2019, nr 2, s. 171-188

DOI: http://dx.doi.org/10.18290/kip.2019.8.2-11

\author{
Maciej Kołodziejski
}

\title{
POSOBOROWE IMPLIKACJE DOTYCZĄCE EKLEZJOLOGII PRAWA KOŚCIELNEGO W DOKTRYNIE POLSKICH KANONISTÓW
}

Kanonistyka w okresie po pierwszej kodyfikacji zajmowała się z zasady egzegetyczno-podręcznikową analizą norm kodeksowych, nie zawsze wrażliwą na wymagania teologicznego uzasadnienia, jak również na określenie własnej metody pracy badawczej. W poszczególnych działach kanonistyki aż do Soboru Watykańskiego II, jedynym punktem odniesienia była w zasadzie rzymska szkoła kościelnego prawa publicznego. W tej szkole po raz pierwszy zastosowano do Kościoła w sposób systematyczny kategorię „społeczności doskonałej”. Rozumie się ją przez to, że każda instytucja ludzka posiada wszystkie środki prawne, które są niezbędne do osiągnięcia własnego celu. Z pewnością taki zabieg metodologiczny pozwalał Kościołowi uzyskać niezależność wobec coraz silniejszych tendencji samostanowienia się państwa liberalnego jako jedynej i właściwej społeczności suwerennej. Łatwo jednak wyczuć słabość tego założenia, kiedy popatrzymy na odniesienie do teologicznego uzasadnienia struktury prawnej, która istnieje w Kościele [Martin de Agar 2007, 7-18].

Na gruncie teologicznym można również znaleźć wiele uzasadnień, które chcą widzieć prawo nie jako rzeczywistość wewnętrzną, choć należącą do istoty Kościoła, albo takie, które nie przypisują kanonistyce związku

Ks. MGR LIC. MACIEJ KoŁodZIEJSKI - doktorant, Katedra Historii, Teorii i Norm Ogólnych Prawa Kanonicznego, Wydział Prawa Kanonicznego Uniwersytetu Kardynała Stefana Wyszyńskiego w Warszawie; adres do korespondencji: ul. Dewajtis 5, 01-815 Warszawa, Polska; e-mail: kmaciu@wp.pl; https://orcid.org/0000-0002-8972-2709 
z jego tajemnicą i zbawczą funkcją. Niniejszy artykuł poświęcony jest ogólnej analizie eklezjologii prawa kościelnego. Na samym początku zostanie przedstawiony problem natury Kościoła jako punkt wyjściowy całej eklezjologii Soboru. To namysł nad tym, co Kościół mówi sam o sobie oraz w jaki sposób chce zrealizować własną misję i zachować swoją tożsamość. Dalej zostanie ukazana koncepcja osoby w Kościele. Wydaje się, że nie można było pominąć tej kwestii, gdyż wiele miejsca w opracowaniach kanonistów zostało poświęcone osobowości kanonicznej, relacji pojęć christifidelis persona oraz próbie odpowiedzi na podmiotowość działania w Kościele. Ponadto nie można pominąć pojęcia wspólnoty (communio), na której również koncentruje się nauka Soboru Watykańskiego II o Kościele. Dotychczasowe próby ujęcia modelu w formie societas perfecta okazały się niewystarczające dla pełniejszego rozumienia natury wspólnoty kościelnej.

\section{PROBLEM NATURY KOŚCIOŁA}

Sobór Watykański II w sposób kluczowy zaważył na refleksji dotyczącej tajemnicy Kościoła. Papież Jan XXIII zaznaczył na samym początku, iż celem Soboru nie będzie formułowanie nowych prawd wiary, ale wysiłek służący namysłowi nad wyznawanymi prawdami wiary tak, aby członkowie Kościoła mogli coraz lepiej rozumieć i realizować w nim swoje powołanie [Choromański 2012, 18]. W przemówieniu otwierającym II sesję Soboru papież Paweł VI niejako wyznaczył Ojcom soborowym zadanie poprzez postawione pytanie: Ecclesia, quid dicis de te ipsa?, aby na nowo opisać Kościół w jego naturze, misji i bycie. Zadanie to miało pozwolić opisać jego tajemnicę $w$ języku współczesnym, pamiętając zarazem o jego specyfice i własnej tożsamości.

Należy zaznaczyć, że Soborowi chodziło o to, by ludzkość lepiej rozumiała Kościół i konsekwentnie zapytać się, na ile kanonistyka polska dała wyraz temu, aby lepiej zrozumieć prawo własne Kościoła oraz czy wraz z próbą głębszego rozumienia jego natury również lepiej pogłębiono rozumienie jego prawa [Sobański 1987b, 3]. To właśnie Kościół stał się centralnym tematem Soboru Watykańskiego II, gdzie dostrzeżono potrzebę głębszego jeszcze wyjaśnienia natury i posłannictwa Kościoła [Nagy 1968, 
93-94] ${ }^{1}$. Powołana w 1963 r. Komisja dla Rewizji Kodeksu Prawa Kanonicznego odłożyła swoje prace aż do zakończenia Soboru, aby nauka soborowa stała się niejako przełożona $\mathrm{w}$ kodeksowych postanowieniach ${ }^{2}$. Papież Jan Paweł II w konstytucji apostolskiej Sacrae disciplinae leges podkreślił właśnie owe przeniesienie eklezjologii soborowej jako narzędzie zachowania porządku wspólnoty kościelnej³, szczególnie zarysowane w konstytucji dogmatycznej Lumen gentium ${ }^{4}$ oraz duszpasterskiej Gaudium et spes. Ojcowie soborowi pytali się, czym Kościół jest sam w sobie i jaka jest jego natura ${ }^{5}$. Już na samym początku można stwierdzić głębsze ujęcie natury Kościoła. Dawniej nazywano go społecznością doskonałą, akcentując wymiar zewnętrzny oraz odnosząc w relacji do struktur społeczności świeckiej [Sobański 1969, 4-6]. Nowości, które znalazły swoje miejsce w Kodeksie Prawa Kanonicznego z 1983 r. ${ }^{6}$ zostają uzasadnione przez eklezjologię Soboru w nauce o Kościele jako Ludzie Bożym i wspólnocie, relacjach pomiędzy Kościołem powszechnym i partykularnym, kolegialności i prymacie, służebnym charakterze władzy hierarchicznej, obowiązkach i prawach wszystkich wiernych oraz ekumenizmie [Tenże 1985, 1; Łukaszyk 1969, 41-51].

Temat Kościoła jest przedmiotem zainteresowania wielu dyscyplin. W analizowanej tematyce zostanie przybliżona jego natura oraz relacja do innych wspólnot ludzkich. W sposób szczególny zaakcentowana zostanie

\footnotetext{
${ }^{1}$ Sacrosanctum Concilium Oecumenicum Vaticanum II, Constitutio pastoralis de Ecclesia in mundo huius temporis Gaudium et spes (7.12.1965), AAS 58 (1966), s. 1025-115 [dalej cyt.: GS]; tekst polski w: Sobór Watykański II, Konstytucje, dekrety, deklaracje. Tekst polski. Nowe tłumaczenie, Pallottinum, Poznań 2002, s. 526-606, nr 1.

${ }^{2}$ Pontificia Commissio Codici Iuris Canonici Recognoscendo, Acta Commissionis. Labores preparatorii, „Communicationes” 1 (1969), s. 36.

${ }^{3}$ Ioannes Paulus PP. II, Constitutio apostolica Sacrae disciplinae leges (25.01.1983), AAS 75 (1983), pars II, s. VII-XIV; tekst polski w: Kodeks Prawa Kanonicznego, przekład polski zatwierdzony przez Konferencję Episkopatu, Pallottinum, Warszawa 2008, s. 9.

${ }^{4}$ Sacrosanctum Concilium Oecumenicum Vaticanum II, Constitutio dogmatica de Ecclesia Lumen gentium (21.11.1964), AAS 57 (1965), s. 5-75 [dalej cyt.: LG]; tekst polski w: Sobór Watykański II, Konstytucje, s. 104-66.

5 „Ponieważ Kościół jest w Chrystusie niejako sakramentem, czyli znakiem i narzędziem wewnętrznego zjednoczenia z Bogiem i jedności całego rodzaju ludzkiego, przeto podejmując naukę poprzednich soborów, pragnie on wyjaśnić dokładniej swoim wiernym i całemu światu swoją naturę i powszechne posłannictwo" (LG 1).

${ }^{6}$ Codex Iuris Canonici auctoritate Ioannis Pauli PP. II promulgatus (25.01.1983), AAS 75 (1983), pars II, s. 1-317; tekst polski w: Kodeks Prawa Kanonicznego, przekład polski zatwierdzony przez Konferencję Episkopatu, Pallottinum, Warszawa 2008 [dalej cyt.: KPK/83].
} 
struktura widzialna i zewnętrzna Kościoła w aspekcie prawnym [Sztafrowski 1976, 15].

Słusznym wydaje się być, że potrzebna jest w tym miejscu refleksja nad właściwym rozumieniem określenia „prawo Kościoła”, które jedynie właściwie można rozumieć $\mathrm{w}$ jego kościelnej specyfice. Jeżeli specyfika ta pozostaje oddzielona, pozostaje również oddzielony aspekt eklezjalny od prawnego, a wtedy poznanie i zrozumienie prawa kościelnego pozostaje niemożliwe. Prawo Kościoła bez określenia „kościelne”, to znaczy bez elementu eklezjalnego, nie ma racji bytu [Sobański 1987b, 2-4; Nagy 1965, 20-24]. Rozumienie określonych rzeczy jest konsekwencją tego, co jest już znane. Refleksję budujemy na bazie tego, co nowe i już zastane. Każde nowo wypracowane pojęcie buduje na wcześniej już znanym. A zatem jakość prawa kanonicznego na gruncie kościelnym jest obecna w taki sposób, w jaki jest uświadomiona przez tych, którzy prawo stanowią, interpretują oraz stosują. Punktem wyjściowym dla uchwycenia istoty prawa kanonicznego jest odniesienie się do pojęć, które zawierają w sobie rozumienie kościelności. Inaczej można zgubić istotną jego właściwość, bez której prawo Kościoła nie istnieje [Sobański 1987b, 4].

Wydaje się zatem, iż warto na bazie tego zestawienia zapytać się, w jaki sposób nauka Soboru wpłynęła na pracę kanonistów polskich, aby nauka eklezjalna dała wyraz $\mathrm{w}$ zastosowaniu prawa kościelnego w pismach i praktyce prawniczej, które prezentują oraz w jaki sposób dała wyraz temu, aby jeszcze głębiej zapytać o istotę Kościoła w jego tajemnicy. Refleksje takie będą przedmiotem zainteresowań w odniesieniu do całej kanonistyki, jak również do KPK/83 w sposób szczególny w aspekcie eklezjologicznym, który jest tak istotny z punktu widzenia nauki Vaticanum II [Sobański 1985, 3-30].

Należy zatem przejść do konkretnych założeń, jakie są przedstawiane na gruncie kanonistycznej literatury polskiej, szczególnie w polskich czasopismach kanonistycznych doby soborowej wydawanych na wydziałach prawa kanonicznego. Dają one wyraz temu, czym polscy kanoniści zajmowali się w swoich badaniach naukowych oraz w jaki sposób nauka soborowa znajdowała lub nie w nich swoje potwierdzenie.

Na pierwszym miejscu warto poczynić namysł nad odniesieniem kanonistyki do teologii. We wspominanych już bowiem wyżej aspektach dotyczących eklezjologii, autorzy opracowań kanonistycznych mocno do tego 
aspektu nawiązują ${ }^{7}$. Należy nadmienić, iż odniesienie do nauk teologicznych mogłoby być mało produktywne, gdyby potraktować prawo jako pochodną teologii lub jej jedynie prawny aspekt. W tym zestawieniu kanonistyka powinna być traktowana jako jedna $\mathrm{z}$ nauk badająca tajemnicę Kościoła $\mathrm{z}$ właściwego sobie punktu widzenia oraz przy pomocy własnych metod, mając na uwadze przede wszystkim porządek zbawienia. W okresie klasycznym każdy podręcznik historii dogmatów opatrzony był komentarzem kanonisty, którzy uważali się za czynnych twórców nauki teologicznej. Dyskusje między teologami i kanonistami odżyły dopiero w czasie Soboru Watykańskiego II [Sobański 1987b, 6].

Warto też nawiązać w rozważaniach dotyczących definicji Kościoła do tego, w jaki sposób podjęto próbę redefinicji Kościoła zaraz po encyklice Mystici Corporis Christi $^{8}$, co miało wielki wpływ na prace soborowe dotyczące tej materii, a zarazem na kwestię „eklezjologii Kodeksu”. Choć encyklika została wydana w 1943 r. miała wielki wpływ na nowe rozumienie Kościoła oraz poruszała problem przynależności niekatolików do Kościoła, co w sposób istotny stało się zainteresowaniem wielu kanonistów w wymiarze prawnym opisujących przynależność do wspólnoty kościelnej [Pylak 1960, 45-71; Nagy 1960, 45]. Postawiono zarzut definicji Bellarmina, która określa Kościół jako strukturę widzialną i prawno-społeczną, a jednocześnie pozbawioną elementu niewidzialnego wraz z ogromem łask nadprzyrodzonych. Uważano, iż element widzialny pozostaje w hierarchii na drugim miejscu i jest przydatny tylko z punktu widzenia katechetycznego. Nie wyczerpuje jednak całej prawdy o Kościele, dlatego definicję tę potraktowano jako quasi definicję Kościoła. Nowe zaproponowane określenie dotyczące Kościoła mówi o Mistycznym Ciele Chrystusa. W takiej właśnie formie weszło do projektu konstytucji dogmatycznej o Kościele na Soborze Watykańskim oraz stanowiło punkt wyjścia i myśl przewodnią całego schematu [Pylak 1959, 12].

W rozważaniach dotyczących tajemnicy Kościoła z punktu widzenia kanonistycznego, ale i również teologicznego, w sposób pełny nie da się wyczerpać definicji Kościoła, ponieważ właśnie w aspekcie niewidzialnym pozostanie on nieuchwytny w ramach badań czysto empirycznych. Dlatego

${ }^{7}$ Por. m.in. Pylak 1957, 123-36; Tenże 1960, 45-71; Nagy 1960, 123-25; Florkowski 1960, 125-27; Nagy 1973, 5-30.

${ }^{8}$ Pius PP. XII, Litterae encyclicae de Mystico Iesu Christi Corpore deque nostra in Eo cum Christo coniunctione Mystici Corporis Christi (29.06.1943), AAS 35 (1943), s. 193-248. 
zauważa się, że prawo kanoniczne powinno badać z własnego punktu widzenia ten porządek, a kanonistyka nie powinna określać się przez relacje do innych nauk, lecz poszukiwać własnych metod prowadzących do celu [Sobański 1987b, 7].

Czy zatem kanonistyka w Polsce, szczególnie w opracowaniach posoborowych, wyciągnęła wnioski, że Kościół jako tajemnica jest rzeczywistością złożoną, ale też niepodzielną? Czy przedmiot kanonistyki, którym jest prawo kościelne jest rzeczywistym prawem Kościoła i nawet jeśli pozostaje ujęte $\mathrm{w}$ formie ustawy podlegać może również interpretacji teologicznej? Większość kanonistów stwierdza, że zajmuje się Kościołem w aspekcie prawnym. Należy pamiętać, aby przez aspekt prawny nie rozumieć jedynie widzialnej strony, czyli Kościół oderwany od wewnętrznych treści. Ten aspekt powinien być widziany całościowo, bo tylko wtedy w odniesieniu do Kościoła jest prawidłowy. A zatem Kościół ujęty w aspekcie prawnym to nie tylko zewnętrzne jego ujęcie. To refleksja nad „całością Kościoła” właśnie poprzez ten aspekt [tamże]. Tę refleksję możemy zauważyć w opracowaniach dotyczących Synodu Rzymskiego, który był niejako inspiracją dla Vaticanum II, jak również w pracach przygotowawczych do Soboru. Proponowane postulaty znajdują swoje miejsce w refleksjach kanonistów polskich dotyczących nowego spojrzenia na Kościół. I choć przeważa często refleksja duszpasterska, to wielu podejmuje próbę syntezy postulatów soborowych $\mathrm{z}$ obowiązującym prawem i niejako $\mathrm{w}$ swych relacjach daje podwaliny pod nowe rozumienie całości prawa Kościoła w aspekcie eklezjologicznym ${ }^{9}$.

Polscy kanoniści w swoich opracowaniach, czy to z okresu przygotowawczego do Soboru, czy bezpośrednio po jego zakończeniu, zwracają uwagę na nową systematykę Kodeksu. Zauważono, że oprócz swego logicznego uporządkowania jest zarazem środkiem teologicznego przekazu, szczególnie w kwestii, jaką jest walor eklezjologiczny. Jest to temat, który również mocno zajmuje uwagę autorów zagranicznych, choć K. Mörsdorf, za H.U. von Balthasar'em jest zdania, że schemat, który przyjął Sobór, jedynie w niewielkim stopniu odzwierciedla wypowiedzi eklezjologiczne w tej kwestii [Gerosa 1999, 50-55]. Natomiast czołowy polski kanonista R. Sobański zaznacza, że w sposób wyjątkowo niefortunny pozostała nazwa Księgi II - „Lud Boży”. Jego zdaniem postanowiono w ten sposób dostosować

${ }^{9}$ Por. m.in. Sołtyszewski 1959a, 378-82; Tenże 1959b, 439-43; Tenże 1959c, 371-77. 
Kodeks do eklezjologii soborowej, ale ograniczenie nazwy do jednej z ksiąg Kodeksu zawęża mocno całe odniesienie. Przecież do Ludu Bożego zalicza się sakramenty, słowo przepowiadane, dobra doczesne oraz sankcje, a nie jedynie prawa i obowiązki wiernych, jak zaznacza. Dopiero w rzeczywistości całego KPK/83 wszystkie te działania w sposób właściwy sobie się aktualizują, a nie jedynie w uporządkowanym zestawieniu praw i obowiązków konkretnego wiernego [Sobański 1985, 5].

Autorzy polskich opracowań posoborowych zaznaczają, iż słusznie Księga II nie została zatytułowana „O kościelnej władzy rządzenia”, a tytuł De potestate regiminis znalazł się $\mathrm{w}$ normach ogólnych. Widzi się tu wymowę eklezjologiczną, gdzie już sama Komisja przygotowawcza zaznaczyła, iż semantyka bardziej teologiczna nawiązuje do nauki Soboru Watykańskiego II w schemacie trzech urzędów Kościoła. Należy również zaznaczyć, iż powstała wątpliwość, jak sprecyzować zadanie w Kościele wiernych świeckich. Zadania pasterskie powierzone są tym, którzy otrzymali święcenia, a to mogłoby naruszyć pogląd o podstawowych funkcjach osób świeckich ${ }^{10}$.

Kolejnym dowodem na to, że cały Kościól, to jest wszyscy wierni mają być podmiotem jego aktywności, świadczy tytuł Części I Księgi II pt. „Wierni”. Jest to istotne z punktu widzenia wszystkich członków wspólnoty kościelnej. Kodeks ma nie być zbiorem przepisów jedynie dla duchownych, ale wszyscy członkowie są prawnie zorganizowaną wspólnotą. Natomiast jako mankament obecnego zestawienia tytułów Księgi II autorzy zaznaczają, iż bardziej adekwatne byłoby posłużenie się schematem propozycji z 1980 r., gdzie prałatury personalne oraz stowarzyszenia wiernych zestawione byłyby $\mathrm{z}$ instytutami życia konsekrowanego, instytutami świeckimi oraz stowarzyszeniami życia apostolskiego. Również ze słuszną krytyką spotkała się propozycja umieszczenia prałatur personalnych wśród Kościołów partykularnych [Sobański 1985, 8-11].

\section{POZYCJA OSOBY W KOŚCIELE}

W ujęciu chrześcijańskim każdy człowiek jest osobą jako istota wyposażona $\mathrm{w}$ rozum i wolną wolę, dzięki czemu staje się podmiotem praw

${ }^{10}$ Pontificia Commissio Codici Iuris Canonici Recognoscendo, Acta Commissionis. Index generalis provisorius novi Codicis Iuris Canonici, Nota, „Communicationes” 9 (1977), s. 230. 
i obowiązków. Wynikają one z jego natury i dlatego są uniwersalne, nienaruszalne i niezbywalne ${ }^{11}$. Osoba ludzka jest i powinna być, w chrześcijańskiej wizji świata, podmiotem i celem wszystkich działań ze względu na swoje centralne miejsce (GS 21). Bez wątpienia godność osobowa przysługuje wszystkim istotom ludzkim, gdyż są one zdolne do samostanowienia i nie wolno jej traktować jako środka do celu, lecz zawsze jako cel sam w sobie. W ujęciu personalistycznym osoba charakteryzuje się dynamizmem, zawierającym w sobie strukturę biopsychiczną, jak również egzystencjalną realizację człowieczeństwa [Wojtyła 1985, 45n.]. Myśl chrześcijańska pojęcie osoby rozwinęła na bazie nauki o Trójcy Świętej i chrystologii, gdzie wydobywano elementy substancjalne, jak i racjonalne. Miarą definicji w swoim najszerszym odniesieniu stała się definicja Boecjusza, którą również posłużył się Akwinata [Sobański 1997, 3-5].

Jeszcze do niedawna kanonistyka nie posiadała znacznego dorobku poświęconego refleksji o osobie jako istocie ludzkiej. Opierano się z zasady w definicji jako na podmiocie działającym, który posiada swoje konkretne zadanie. Dzięki temu jednak rozwinięto naukę o osobie moralnej, określanej jako persona christianorum już w edykcie z $313 \mathrm{r}$. Na gruncie prawa kanonicznego każda istota ludzka jest osobą, ale warto zaznaczyć, iż tam, gdzie jest mowa o określeniu homo, nie precyzuje się, czy jest ochrzczona czy nie ${ }^{12}$. Natomiast na określenie podmiotu zdolności prawnej używa się określenia persona [tamże].

Te wstępne rozważania dotyczące osoby mają swoje odniesienie do tego, w jaki sposób posłużono się pojęciem osoby w KPK/83 i co ważniejsze w jaki sposób rozumie się to określenie. W aktach Komisji dla Rewizji Kodeksu Prawa Kanonicznego można znaleźć wyjaśnienie, że Księga II KPK/83 posługuje się określeniem osoby jako członka Ludu Bożego, a nie używa pojęcia osoby w aspekcie prawnym ${ }^{13}$. Słuszne zatem wydaje się podnieść pytanie, w jakim aspekcie mówi się o osobach w KPK/83? Refleksję dotyczącą tego zagadnienia podejmują kanoniści polscy wchodząc $\mathrm{w}$ dyskusję z innymi autorami opracowań czasu przemian soborowych. Pojawił

${ }^{11}$ Ioannes PP. XXIII, Litterae encyclicae de pace omnium gentium in veritate, iustitia, caritate, libertate constituenda Pacem in terris (11.04.1963), AAS 55 (1963), s. 257$304, \mathrm{nr} 9$.

${ }^{12}$ Wyjątek stanowi kan. $1086 \S 1$, gdzie określenie persona oznacza osobę nieochrzczoną.

${ }^{13}$ Pontificia Commissio Codici Iuris Canonici Recognoscendo, Acta Commissionis. Schema Codicis Iuris Canonici, „Communicationes” 14 (1982), s. 122-27. 
się problem w myśleniu kanonistycznym co do pojęcia „osoby”, który miałby toczyć się dwoma torami: teologicznym i prawniczym, co mogło wynikać z braku dostrzeżenia (a może i głębszego zrozumienia) teologicznego znaczenia pojęć kanonistycznych [Sobański 1985, 245n.], podobnie, jak próbowano kanonistyce przypisać jedynie zajmowanie się zewnętrzną strukturą Kościoła, a nie jego refleksję nad „całym” Kościołem w swej istocie właśnie $\mathrm{z}$ tej perspektywy.

Wprowadzenie do tekstu normatywnego pojęcia christifidelis może dowodzić, że Kodeks posiada niejako „dwie dusze”, prawną i teologiczną. Ta pierwsza odpowiada za techniczne konstrukcje prawne, a druga nadaje specyficzną rację porządku prawnego. Połączenie obu płaszczyzn stanowi cechę charakterystyczną nowego Kodeksu.

Zwolennicy dwuaspektowego ujęcia podnoszą, iż określenie persona ma swój czysto jurydyczny charakter, natomiast christifidelis to pojęcie teologiczne, którego punktem odniesienia jest Lud Boży. Zgodnie z tym poglądem - persona - nie jest w stanie wyrazić co do działania i godności pozycji prawnej wiernych w Kościele. Za utrzymaniem tego terminu przemawia fakt, iż może on być stosowany w tych momentach kodeksowych, które nie są uregulowane faktem chrztu, a także zapewnia łatwość komunikowania się z prawem świeckim [Lo Castro 1985, 50-60; Sobański 1997, 3-5].

Autorzy opracowań zwracają uwagę na treść kan. 96, gdzie jest mowa nie o zdolności prawnej jako takiej, ale o zdolności prawnej w Kościele, co również nie wyklucza zdolności prawnej nieochrzczonych. Należy w tym miejscu nadmienić, że dla zdolności prawnej będącej skutkiem chrztu fundamentem jest osoba ludzka. Można zatem skonstatować, że „podłożem” dla osobowości kanonicznej jest właśnie ta naturalna. Inaczej mówiąc, człowiek ochrzczony nie posiada osobowości naturalnej i chrześcijańskiej, lecz pozostaje „całą” osobą w Kościele [Sobański 1997, 4].

Każdy człowiek przed przyjęciem chrztu posiada jedynie osobowość naturalną, ale nie posiada jeszcze praw i obowiązków w Kościele, ponieważ jeszcze do niego nie należy. G. Michiels komentując kan. 87 Kodeksu Prawa Kanonicznego z 1917 r. ${ }^{14}$, proponował odpowiedź na to, w jaki sposób człowiek zyskuje osobowość prawną w Kościele. Nie używał określenia „przynależność do Kościoła”, czy „członek Kościoła”, ale określenia „osoba”,

${ }^{14}$ Codex Iuris Canonici Pii X Pontificis Maximi iussu digestus Benedicti Papae XV auctoritate promulgatus (27.05.1917), AAS 9 (1917), pars II, s. 1-593 [dalej cyt.: $\mathrm{KPK} / 17]$. 
aby jeszcze bardziej podkreślić znaczenie i skutki chrztu. Wśród opinii komentatorów znaleźć można niemalże jednoznaczne stwierdzenia, podkreślające podmiot praw i obowiązków oraz użycie pojęcia osoby w sensie prawnym [Michiels 1971, 90-92].

Bardzo mocno komentuje tę kwestię E. Sztafrowski, który aplikacji przesłanek soborowych na grunt prawa kościelnego poświęcił wiele miejsca. Zaznacza on, iż kan. $87 \mathrm{KPK} / 17$ nie jest do końca pełnym odzwierciedleniem przynależności do Kościoła, co było przecież tak mocno dyskutowane podczas obrad soborowych. Konstytucja soborowa Lumen gentium definiuje, iż to chrzest jest bramą wcielającą do Kościoła dodając zarazem, że również katechumeni cieszą się pewną pozycją prawną w Kościele. Wyraźnie postulat pod adresem przyszłego Kodeksu w tej materii dookreślili jeszcze mocniej Ojcowie Soboru w dekrecie o misyjnej działalności Kościoła [Sztafrowski 1976, 168] ${ }^{15}$.

W toczącej się dyskusji wokół problematyki przynależności do Kościoła nowe elementy wniosła również encyklika Mystici Corporis Christi oraz dekret Unitatis redintegratio ${ }^{16}$. Przyjęcie wielowarstwowej przynależności do Kościoła to jeden z najbardziej istotnych elementów, jakie wnoszą te dokumenty. Owa przynależność nie ma dotyczyć jedynie chrztu, ale także innych sakramentów. Urząd Nauczycielski Kościoła w wielu miejscach poruszał tę kwestię, która do tej pory nie doczekała się głębszej analizy przez kanonistów i teologów, ale daje nową perspektywę dla pogłębienia wspomnianego zagadnienia. Szereg opracowań oraz wyciągnięcie przez prawo właściwych wniosków dotyczących przynależności do Kościoła z racji chrztu i innych sakramentów pozwalają rzucić nowe światło na problematykę osobowości kościelnej oraz problematykę, która nie będzie jedynie opierać się na teorii, iż „można być w Kościele podmiotem praw i obowiązków, a nie być członkiem Kościoła” [Sobański 1970, 148].

\footnotetext{
15 „Stanowisko katechumenów należy jasno określić w nowym Kodeksie. Są już bowiem oni złączeni z Kościołem, są już domownikami Chrystusa, a nierzadko prowadzą życie nacechowane wiarą, nadzieją i miłością". Zob. Sacrosanctum Concilium Oecumenicum Vaticanum II, Decretum de activitate missionali Ecclesiae Ad gentes Divinitus (7.12.1965), AAS 58 (1966), s. 947-90; tekst polski w: Sobór Watykański II, Konstytucje, s. 433-71, nr 14.

16 Tenże, Decretum de Oecumenismo Unitatis redintegratio (21.11.1964), AAS 57 (1965), s. 90-112; tekst polski w: Sobór Watykański II, Konstytucje, s. 193-208. Por. Łukaszyk 1967, 61-81.
} 
Po raz pierwszy jesteśmy również świadkami zestawienia: „obowiązki i prawa”. W pracach przygotowawczych posłużono się schematem: „prawa i obowiązki" chrześcijanina. Jednak uzasadniano tę kolejność koncepcją, gdzie chrześcijanin jest zobowiązany do czynnego udziału w posłannictwie i misji Kościoła. Jednak ta koncepcja na gruncie eklezjologicznym należy do jednej z najsłabszych w systematyce kodeksowej. Zarzuca się jej często, iż działa demotywująco przy określaniu poszczególnych praw wiernych, jak również nie zawsze wywiera wpływ na obecne uświadomienie sobie praw i obowiązków chrześcijanina ${ }^{17}$. Polemizując na tym polu z E. Corecco, Sobański jest zdania, iż ta zasada nie odpowiada w pełni dynamice praw chrześcijanina. Jako uzasadnienie swej argumentacji przywołuje naukę o eklezjalnych skutkach chrztu ${ }^{18}$. Jakakolwiek przewaga w korelacji prawa - obowiązki, może prowadzić do nierównowagi, a ta z kolei może negatywnie wpływać na życie wspólnoty [Gałkowski 2007, 269].

Również inni autorzy prac poświęconych dynamice „osoby w Kościele”, analizujący proces odnowy soborowej, zaznaczają, iż człowiek staje się chrześcijaninem przez obdarowanie, które może zaistnieć w momencie przyjęcia chrztu oraz wyrażenia wiary. A zatem zdolność do działania w Kościele nie może stanowić swoistego dodatku do innych cech wiernego. Dary chrztu i predyspozycje naturalne mają nadawać dynamizm całej wspólnocie. Wydaje się również słusznym zarzut stawiania obecnemu Kodeksowi, jakoby prawa wiernych zostały w nim zawarte nieco defensywnie. Zamiar aktywizacji wiernych realizuje się raczej z dystansem niż nowym spojrzeniem. Wychodzenie od obowiązków stało się być może zbyt ścisłym stawianiem granic uprawnień. Porządek wspólnoty kościelnej ma stwarzać możliwości rozkwitu. Nowego przemyślenia (teologicznego i kanonistycznego) wymagają z pewnością kwestie aktywnego połączenia wszystkich wiernych ze strukturą hierarchiczną ${ }^{19}$.

${ }^{17}$ Pontificia Commissio Codici Iuris Canonici Recognoscendo, Acta Commissionis. Coetus Studiorum de Populo Dei (18.10.1979), „Communicationes” 12 (1980), s. 74-80.

18 Jako eklezjalne skutki chrztu przywołane w kan. 96 oraz kan. 204 wymienia się: a) nieprzerwaną i niepodważalną nauką Kościoła jest, iż przez chrzest człowiek staje się jego członkiem; b) jako dogmat wiary uznaje się, że chrzest odradza wewnętrznie człowieka, który otrzymuje synostwo Boże; c) chrzest wyciska duchowy i niezamazalny znak, który daje udział w kapłaństwie Chrystusa i uprawnia do udziału w kulcie Kościoła (por. LG 25). Zob. Sobański 1986, 4-10.

${ }_{19}$ Por m.in. Żurowski 1976, 39-50; Tenże 1967a, 9; Sobański 1997, 7-9; Pawluk 1979, 39-54. 
Sobór Watykański II wspomnianym zagadnieniem zajął się w kilku uchwałach. Nie znajdziemy tutaj swego rodzaju quasi Deklaracji Praw Człowieka, choć Ojcowie soborowi składali propozycję podobnego dokumentu [Beyer 1969, 30-58]. Po zakończeniu Soboru podjęto próbę usystematyzowania praw i obowiązków wszystkich wiernych w projekcie Fundamentalnego Prawa Kościoła ${ }^{20}$. Słusznie zatem w czasopismach kanonistycznych na gruncie polskim autorzy podejmują wysiłek analityczny dotyczący wspomnianych zagadnień proponując nową perspektywę. Tym bardziej, iż okres posoborowy w zakresie zagadnień uprawnień osoby ludzkiej stanowił w swym czasie centrum zainteresowania oraz był przedmiotem deklaracji międzynarodowych, choćby wspomnieć tę z 10 grudnia $1948 \mathrm{r}$. [Machowski 1968, 190-200; Andrzejczak 1970, 75-87].

\section{MODEL SOCIETAS CZY COMMUNIO?}

Na określenie Kościoła uchwały Vaticanum II używają nazwy communio, jak również societas. Wybrana analiza tekstów soborowych niektórych autorów ujawnia w nich niejako „dwie eklezjologie” [Rola 1985, 250n.]. Rozważając walor eklezjologiczny Księgi I KPK/83 można wnioskować, iż odzwierciedla ona „eklezjologię społeczności”. Z drugiej zaś strony brak w niej odniesienia do „eklezjologii communionis”, co miało być podyktowane względami praktycznymi. Kościół jest wspólnotą wiary, ale nie można zapominać, że dla prawnika istotny jest fakt, iż jest on także społecznością. Po raz kolejny wyłania się dychotomiczny obraz Kościoła: wspólnoty wiary oraz społeczności. Wydaje się, że myśl kanonistyczna dalej potrzebuje pojęcia społeczności. Połączenie faktów prawnych i wydarzeń teologalnych, staje się możliwe właśnie przez kategorię społeczności. Wielu kanonistów zainspirowanych nauką soborową podejmuje ten aspekt na gruncie prawa kościelnego poddając pod analizę z różnych punktów widzenia $^{21}$. Przyjmując model societas perfecta, starają się uzasadnić bardzo

${ }^{20}$ Fundamentalne prawa i obowiązki człowieka zawarto w kan. 10-25 Schematu, zob. Pontificio Commissio Codici Iuris Canonici Recognoscendo, Schema Legis Ecclesiae Fundamentalis (24.05.1969); tekst polski w: Posoborowe prawodawstwo kościelne, zebrał E. Sztafrowski, t. IV, z. 3, Akademia Teologii Katolickiej, Warszawa 1972, s. 2026, $\mathrm{nr}$ 8295-8313.

${ }^{21}$ Por. m.in. Żurowski 1977, 67-85; Tenże 1967b, 59-88; Sobański 1987a, 3-30; Sztafrowski 1976, 19-22. 
często jedynie wymiar prawny (zewnętrzny) Kościoła. Inni uważają, iż pojęcie communio to wyraz jego spirytualizacji [Rola 1985, 249-55].

Dla Kościoła pierwotnego centralnym pojęciem dla jego rozumienia jest koinonia. Pogłębiona refleksja nad tym określeniem prowadzi do wniosku, iż chodzi tu o wspólnotę z kimś przez wspólny udział [Sobański 1987a, 5]. Koinonia to również relacje społeczne poprzez wspólne dzielenie się określonym dobrem. Ten, kto otrzymuje, ma również obowiązek dzielenia się, co bardzo mocno podkreślone jest w listach św. Pawła (m.in. 1Kor 1,9; Flp 2,1; Gal 2,9; Flm 6). Zarówno communio, jak i societas swoje źródło znajdują właśnie w tym pierwotnym rozumieniu koinonia [Gałkowski 2007, 379]. Oba określenia wyrażały społeczną świadomość wspólnoty chrześcijan, którą zyskała poprzez udział w darach zbawczych. Jedno i drugie w końcu jest określeniem wyznawców tej samej wiary [Kasper 2016, 39-50].

Relacja societas do wspólnoty kościelnej kształtowała się zależnie od zmieniających się warunków historycznych, jak również zmieniała się wraz z głębszym jej rozumieniem [Sobański 1983]. Uchwały Soboru Watykańskiego II określenia societas używają na oznaczenie więzi w wymiarze naturalnym. Jednak w kilku miejscach wskazują na kościelne struktury prawne. Między innymi dlatego mówi się o dwóch torach eklezjologii soborowej [Tenże 1985, 22]. Wiele bodźców znajduje się również w dokumentach i wypowiedziach papieża Pawła VI, który prawo kościelne łączy z pojęciem społeczności w jej wymiarze naturalnym ${ }^{22}$.

Kanoniści stawiali sobie pytanie, w jaki sposób dyrektywy wydawane przez prawodawcę, który kieruje społecznością, mają się do własnego i podstawowego celu Kościoła - zbawienia dusz. Rozróżnienie pomiędzy pierwszorzędnym celem prawa regulującym życie społeczne, jak i ostatecznym, czyli zbawieniem, dało odpowiedź. Prawo umożliwia osiągnięcie zbawienia właśnie przez własny porządek, który pośrednio służy temu celowi i ostatecznie ukierunkowuje na cel ostateczny [Myrcha 1976, 3-20].

Prawo kościelne, które ma być realizowane przez wiernych i ma się stać regułą ich życia, powinno być właściwie rozumiane. Nie sposób tego dokonać, gdy pomija się podstawowe prawdy eklezjologiczne. Prawdy te niestety nie mieszczą się w pojęciu społeczności. Podnosi się zarzut, iż prawo kościelne tak mocno związane $\mathrm{z}$ tym pojęciem, traci swoje miejsce $\mathrm{w}$ tajem-

${ }^{22}$ Paulus PP. VI, Litterae apostolicae motu proprio datae de muneribus Legatorum Romani Pontificis Sollicitudo omnium Ecclesiarum (24.06.1969), AAS 61 (1969), s. 476. 
nicy Kościoła. Poprzez pojęcie societas, nie sposób zrozumieć właściwej sobie roli Kościoła. Sprowadza się to raczej do kwestii związanych z właściwym uregulowaniem życia społecznego. Chrześcijanin ma uchodzić za kogoś sprawiedliwego na forum zewnętrznym Kościoła, ale to $\mathrm{z}$ pewnością nie prowadzi do celu ostatecznego. Refleksja nad pojęciem societas jako analogii Kościoła do innych społeczności, nie jest w stanie wyczerpać eklezjalności prawa kościelnego [Żurowski 1977, 70n.; Sobański 1987a, 22].

Obowiązujące prawo kodeksowe inspirowane zostało również zasadą communio. Nie miało to $\mathrm{z}$ pewnością na celu „spirytualizacji” Kościoła. Stało się słusznym, aby do niego nawiązać, kiedy Kościół chciał wyjaśnić wiernym naturę swojego posłannictwa (LG 1). Nowa świadomość kościelna, dzięki pojęciu communio, znalazła możliwość swojego syntetycznego ujęcia. I choć nie zostało w uchwałach soborowych użyte w kontekście prawnym, to jednak kanoniści nie mogli go pominąć, mając na względzie jego znaczenie w eklezjologii soborowej. Paweł VI określił communio jako cel i normatywne kryterium ustawodawstwa kościelnego ${ }^{23}$.

Jako prawnoteoretyczny i główny cel znaczenia communio, komentatorzy widzą zasadę ukształtowania przez nie prawa kościelnego. Chodzi o likwidację konfliktów w zgodzie z moralnością chrześcijańską. W istocie dopiero pojęcie communio zawiera w sobie możliwość przezwyciężania różnic między jednostkami. Wspólnota kościelna pozostaje zawsze Boskoludzka, dlatego budowanie wspólnoty należy zawsze zaczynać na tej, która już jest dana. To jest możliwe jedynie przy założeniu communio, gdzie prawo kościelne, inaczej jak w societas, wyrasta z życia wspólnoty, a nie jest narzucone $\mathrm{z}$ góry. Osoba jako podmiot prawa kościelnego w kategoriach communio ma charakter aktywny, jest zdolna do przekazywania darów zbawczych pozostałym członkom. Pozycja prawna wiernych jest realizowana dzięki darom zbawczym, a nie jedynie przez akt formalnego przyjęcia [Sobański 1978, 4-20].

Autorzy opracowań zainteresowani eklezjologią KPK/83 poddają analizie cały Kodeks. Jest to wyraźne zainteresowanie i nawiązanie do eklezjologii społeczności. Warto zwrócić uwagę, iż znajduje się tam właśnie wiele dyspozycji bezpośrednio nawiązujących do communio, m.in. o równości wiernych w godności i działaniu, Kościele partykularnym czy pasterskich zada-

\footnotetext{
${ }^{23}$ Tenże, Litterae encyclicae de populorum progressione promovenda Populorum progressio (26.03.1967), AAS 59 (1967), s. 257-99.
} 
niach biskupów. W konstytucji promulgującej Kodeks znajduje się doktryna, która definiuje Kościól jako wspólnotę. Zdaniem wszystkich autorów zajmujących się eklezjologią kodeksową, obok tej właśnie doktryny, widoczna jest doktryna Kościoła jako społeczności. I właśnie tej dychotomii „dwóch eklezjologii” nie udało się do końca uniknąć w obowiązującym Kodeksie [Sobański 1987s, 27n.] ${ }^{24}$.

\section{ZAKOŃCZENIE}

Kanoniści polscy konstatują, iż dla właściwego zrozumienia prawa kościelnego, nie wystarczy uwzględnić jedynie aspekty bazujące na filozofii prawa, ale przede wszystkim należy opierać się na postanowieniach prawa Bożego, co wraz z prawem naturalnym stanowi właściwą strukturę dla społeczności kościelnej. Na pierwszym miejscu należy uwzględnić cel Kościoła, który jest niepowtarzalny dla innych społeczności. Poprzez to prawo Kościoła nie ogranicza się jedynie do aspektu czysto zewnętrznego oraz nie jest systemem minimalistycznym, jeśli chodzi o wymagania w Kościele.

Cały system prawa łączy się z problematyką teologii. Założenia prawa kanonicznego powinny mieć swoje uzasadnienie i podbudowę teologiczną. Obraz Kościoła w Kodeksie Prawa Kanonicznego jest społecznością kierowaną przez osoby. Społeczność ta jest typowa dla wspólnoty kościelnej i kształtu prawnego Kościoła.

Analogicznie do eklezjologii Soboru, eklezjologia KPK/83 nie jest monolitem. Wraz $\mathrm{z}$ wizją kościelnego nurtu społeczności rządzonej przez prawo wyłania się nurt społeczności określanej najczęściej jako eklezjologia wspólnoty.

\section{PIŚMIENNICTWO}

Andrzejczak, Henryk. 1970. „Interpretacja zasady poszanowania praw człowieka dokonana w deklaracji Dignitatis Humanae.” Roczniki Teologiczno-Kanoniczne 17, z. 5:75-97.

Choromański, Andrzej. 2012. „Vaticanum II - Sobór eklezjologicznego przełomu.” Studia Theologica Varsaviensia 2:17-54.

${ }^{24}$ Pontificia Commissio Codici Iuris Canonici Recognoscendo, Acta Commissionis. De Ecclesiae munere docendi, „Communicationes” 15 (1983), s. 91. 
Florkowski, Eugeniusz. 1960. „Traktat o Kościele w wykładzie apologetycznym.” Roczniki Teologiczno-Kanoniczne 7, z. 1:125-27.

Gałkowski, Tomasz. 2007. Prawo - Obowiązek. Pierwszeństwo i współzależność w porządkach prawnych: kanonicznym i społeczności świeckiej. Warszawa: Wydawnictwo UKSW.

Gerosa, Libero. 1999. Prawo Kościoła. Poznań: Pallottinum.

Kasper, Walter. 2016. Faith. New York: Paulist Press.

Lo Castro, Gilberto. 1985. Il soggetto e i suoi diritti nell'ordinamento canonico. Milano: Libreria Editrice Vaticana.

Łukaszyk, Romuald. 1967. „Problem przynależności do Kościoła Chrystusowego w ujęciu Konstytucji Lumen Gentium Soboru Watykańskiego II.” Roczniki Teologiczno-Kanoniczne 14, z. 2:61-81.

Łukaszyk, Romuald. 1969. „Pojęcie Kościoła jako Ludu Bożego w eklezjologii Vaticanum II.” Roczniki Teologiczno-Kanoniczne 16, z. 2:41-51.

Machowski, Jacek. 1968. Prawa człowieka. Warszawa: Wydawnictwo Książka i Wiedza.

Martin de Agar, Joseph. 2007. A Handbook on Canon Law. Philadelphia: Wilson \& Lafleur.

Michiels, Gommar. 1955. Principia generalia de personis in Ecclesia. Paryż: Katolicki Uniwersytet Lubelski, A. \& H. De Bièvre.

Myrcha, Marian. 1976. „Niezbędność prawa.” Życie i Myśl 26:3-20.

Nagy, Stanisław. 1960. „Zagadnienia współczesnej eklezjologii.” Roczniki Teologiczno-Kanoniczne 7, z. 1:123-25.

Nagy, Stanisław. 1965. „Próba nowego spojrzenia na zagadnienie ustanowienia Kościoła.” Roczniki Teologiczno-Kanoniczne 12, z. 2:19-36.

Nagy, Stanisław. 1968. „Via notarum we współczesnej eklezjologii apologetycznej.” Roczniki Teologiczno-Kanoniczne 15, z. 2:93-116.

Nagy, Stanisław. 1973. „Znamię apostolskości Kościoła.” Roczniki Teologiczno-Kanoniczne 20, z. 2:5-30.

Pawluk, Tadeusz. 1979. „Idea podstawowych praw człowieka w prawie kościelnym.” Prawo Kanoniczne 22, nr 3-4:39-54.

Pylak, Bolesław. 1957. „Formułowanie się dogmatycznego traktatu o Kościele.” Roczniki Teologiczno-Kanoniczne 4, z. 3:123-36.

Pylak, Bolesław. 1959. Kościół - Mistyczne Ciało Chrystusa. Projekt konstytucji dogmatycznej na Soborze Watykańskim. Lublin: Towarzystwo Naukowe KUL.

Pylak, Bolesław. 1960. „Problem teologicznej definicji Kościoła.” Roczniki Teologiczno-Kanoniczne 7, z. 1:45-71.

Rola, Marian. 1985. „Sympozjum sekcji kanonistów polskich.” Prawo Kanoniczne 28, nr 1-2:249-55.

Sobański, Remigiusz. 1969. „Osobowość prawna Kościoła katolickiego w świetle konstytucji Lumen Gentium." Prawo Kanoniczne 11, nr 3-4:3-18.

Sobański, Remigiusz. 1970. „Sakramentalne podstawy pozycji prawnej wiernych w Kościele." Prawo Kanoniczne 13, nr 1-2:143-58.

Sobański, Remigiusz. 1983. Kościół jako podmiot prawa. Warszawa: Akademia Teologii Katolickiej.

Sobański, Remigiusz. 1985. „Eklezjologia nowego Kodeksu Prawa Kanonicznego.” Prawo Kanoniczne 28, nr 1-2:3-30. 
Sobański, Remigiusz. 1986. „Iura propter offcia»? Uwagi związane z nagłówkami I i II tytułu I Księgi nowego Kodeksu Prawa Kanonicznego.” Prawo Kanoniczne 29, nr 34:3-12.

Sobański, Remigiusz. 1971. Chrzest jako podstawa jedności Kościoła. Warszawa: Akademia Teologii Katolickiej.

Sobański, Remigiusz. 1978. „Sytuacja metodologiczna prawa kościelnego.” Prawo Kanoniczne 22, nr 1-2:4-20.

Sobański, Remigiusz. 1987a. „W sprawie zasady formalnej Prawa Kościelnego.” Prawo Kanoniczne 30, nr 1-2:3-30.

Sobański, Remigiusz. 1987b. „Wpływ Soboru Watykańskiego II na kanonistykę w Polsce.” Prawo Kanoniczne 30, nr 1-2:47-59.

Sobański, Remigiusz. 1997. „Znaczenie pojęcia osoby w kanonicznym porządku prawnym." Prawo Kanoniczne 40, nr 3-4:3-13.

Sołtyszewski, Stefan. 1959a. „Synod Rzymski.” Prawo Kanoniczne 2, nr 3-4:378-82.

Sołtyszewski, Stefan. 1959b. „Synod Rzymski.” Prawo Kanoniczne 2, nr 3-4:439-43.

Sołtyszewski, Stefan. 1959c. „Z przygotowań do II-go Watykańskiego Soboru Powszechnego." Prawo Kanoniczne 2, nr 3-4:371-77.

Sztafrowski, Edward. 1972. Posoborowe Prawodawstwo Kościelne. Warszawa: Akademia Teologii Katolickiej.

Sztafrowski, Edward. 1976. Prawo kanoniczne w okresie odnowy soborowej. Warszawa: Akademia Teologii Katolickiej.

Wojtyła, Karol. 1985. Osoba i czyn. Kraków: Polskie Towarzystwo Teologiczne.

Żurowski, Marian. 1967a. „Cechy charakterystyczne prawodawstwa kanonicznego w świetle posoborowych tendencji." Prawo Kanoniczne 10, nr 3-4:3-27.

Żurowski, Marian. 1967b. „Prawne aspekty konstytucji Lumen Gentium.” Prawo Kanoniczne 10, nr 1-2:59-88.

Żurowski, Marian. 1976. „Uprawnienia do uczestnictwa we wspólnocie kościelnej pierwszych wieków chrześcijaństwa.” Prawo Kanoniczne 19, nr 3-4:39-50.

Żurowski, Marian. 1977. „Wspólnota kościelna «communio» podstawą prawa kościelnego?" Prawo Kanoniczne 20, nr 1-2:67-85.

\section{Posoborowe implikacje dotyczące eklezjologii prawa kościelnego w doktrynie polskich kanonistów}

\section{Streszczenie}

W rozważaniach dotyczących eklezjologii Kościoła z punktu widzenia kanonistycznego, ale i również teologicznego, wydaje się słusznym stwierdzić, iż w sposób pełny nie da się wyczerpać definicji Kościoła, ponieważ właśnie w aspekcie niewidzialnym pozostanie on nieuchwytny w ramach badań czysto empirycznych. Dlatego słusznie stwierdzają polscy kanoniści, że prawo kanoniczne powinno badać z własnego punktu widzenia ten porządek, a kanonistyka nie powinna określać się przez relacje do innych nauk, lecz poszukiwać własnych metod prowadzących do celu. Kanoniści stawiali sobie pytanie, w jaki sposób dyrektywy wydawane przez prawodawcę, który kieruje społecznością, mają się do własnego i podstawowego celu Kościoła - zbawienia dusz. Dary chrztu i predyspozycje naturalne mają nadawać dynamizm całej wspólnocie. Wydaje się również słusznym zarzut stawiamy obecnemu Kodeksowi, jakoby prawa wiernych 
zostały w nim zawarte nieco defensywnie. Rozróżnienie pomiędzy pierwszorzędnym celem prawa regulującym życie społeczne, jak i ostatecznym, czyli zbawieniem, dało odpowiedź. Prawo umożliwia osiągnięcie zbawienia właśnie przez własny porządek, który pośrednio służy temu celowi i ostatecznie ukierunkowuje na cel ostateczny.

Słowa kluczowe: prawo Kościoła; Vaticanum II; eklezjologia prawa kościelnego; wspólnota

\section{Post-Council Implications Regarding Ecclesiology of Church Law in the Doctrine of Polish Canonists}

\section{Summary}

In the considerations regarding the ecclesiology of the Church from a canonistic and theological point of view, it seems right to spell out that the definition of the Church cannot be fully met. It is because it will remain elusive in purely empirical research. For this reason Polish canonists rightly consider that canon law should examine from own point of view. While disciple of canon law should not be determined itself in relations to other sciences, but should seek its own methods leading to the goal. The canonists framed the question how directives issued by the legislator who manages the community relate to the Church's own and fundamental goal - the salvation of souls. Baptism gifts and natural predispositions are to give dynamism to the whole community. The allegation with regard to the 1983 Code of Canon Law that it contains defensive provisions of law seems to be justified. The distinction between the primary purpose of law regulating social life and the ultimate, that is, salvation, gave the answer. The law makes it possible to achieve salvation through our own order, which indirectly serves this purpose and ultimately directs it to the final goal.

Key words: ecclesiastical law; Vaticanum II; ecclesiology of church law; community

Information about Author: REV. MACIEJ KoŁODZIEJSKI, J.C.L. - Ph.D. student, Department of History, Theory and General Norms of Canon Law, Faculty of Canon Law at the Cardinal Stefan Wyszyński University in Warsaw; ul. Dewajtis 5, 01-815 Warszawa, Poland; e-mail: kmaciu@wp.pl; https://orcid.org/0000-0002-8972-2709 